\title{
Inhibition of Bacterial, Fungal, and Plant Growth by Testae Extracts of Citrullus Genotypes
}

\author{
Howard F. Harrison, Jr. ${ }^{1,2}$, W. Patrick Wechter ${ }^{1}$, \\ and Chandrasekar S. Kousik ${ }^{1}$ \\ U.S. Department of Agriculture, Agriculture Research Service, U.S. \\ Vegetable Laboratory, 2700 Savannah Highway, Charleston, SC 29407
}

Additional index words. allelopathy, Citrullus lanatus var. lanatus, C. lanatus var. citroides, C. colocynthis, Panicum miliaceum, Acidovorax avenae subsp. citrulli, nacterial fruit blotch, Phytophthora capsici, fruit rot

\begin{abstract}
Watermelon [Citrullus lanatus var. lanatus (Thunb.) Matsum \& Nakai] seed and root exudates inhibit germination and seedling growth of plants and growth of pathogenic fungi and bacteria. This study was conducted to determine if extractable components in the testa (seedcoat) contribute to the inhibition previously reported. Testae of eight genetically diverse Citrullus genotypes were extracted first with dichloromethane to remove less polar components and then with $\mathbf{7 0 \%}$ methanol to remove more polar components. The dichloromethane extracts were not inhibitory in a Proso millet radicle growth bioassay; however, they were highly inhibitory to the growth of the fruit blotch bacterial pathogen Acidovorax avenae subsp. citrulli (Aac). All dichloromethane extracts were highly inhibitory to Aac except those from a watermelon breeding line, 4061-x 7 and a $C$. lanatus var. citroides accession, PI 500354. The more polar components extracted in $\mathbf{7 0 \%}$ methanol inhibited Proso millet radicle and Aac growth and Phytophthora capsici zoospore germination. The greatest inhibition of radicle growth was found with $70 \%$ methanol extracts from two watermelon relatives, $C$. lanatus var. citroides [Bailey (Mansf.)] (PI 532738) and C. colocynthis [(L.) Scrad.] (PI 432337). They reduced radicle elongation by $90 \%$ at an extract concentration of $250 \mathrm{mg}$ of tissue extracted per $\mathrm{mL}$ water. The $\mathbf{7 0} \%$ methanol extracts of several genotypes partially inhibited Aac colony formation, but the $C$. lanatus var. citroides accession, PI 532738, was the only genotype with $70 \%$ methanol extracts that completely inhibited the bacterium at $100 \mathrm{mg} \cdot \mathrm{mL}^{-1}$. The $70 \%$ methanol extracts of Charleston Gray, 406-1-x 7, PI 500354, PI 532738, and PI 167125 were highly inhibitory in a Phytophthora capsici zoospore germination bioassay. These results indicate that the testae of Citrullus genotypes contain at least two compounds that are inhibitory to microorganisms and plants in bioassay, and the amount of inhibition caused by the extracts varied among Citrullus genotypes.
\end{abstract}

Allelopathy in the Cucurbitaceae was first reported by Putnam and Duke (1974) who screened the U.S. PI collection of cucumber (Cucumis sativus) germplasm and identified accessions with varying allelopathic potentials. Lockerman and Putnam (1979, 1981) subsequently demonstrated that suppression of Proso millet (Panicum miliaceum) and white mustard (Brassica alba) by cucumber was largely the result of allelopathy and that the most allelopathic genotypes were competitive against weeds. Yu and Matsui (1994) found that cucumber root exudates contained a number of simple and complex phenolic compounds and organic acids that were inhibitory in a lettuce (Lactuca sativus) seedling growth bioassay. The reduced growth of

Received for publication 28 Sept. 2011. Accepted for publication 13 Jan. 2012.

We thank Lance Lawrence, Jennifer Ikerd, and Melanie McMillan for technical assistance.

${ }^{1}$ Research Agronomist and Research Plant Pathologist.

${ }^{2}$ To whom reprint requests should be addressed; e-mail howard.harrison@ars.usda.gov. there are several reports of phytotoxicity caused by seed exudates (Higashinakasu et al., 2004; Kushima et al., 1998; Ohno et al., 2001; Rose et al., 2006; Yamada et al., 1995). Kushima et al. (1998) reported that watermelon seed exudates were inhibitory to the root growth of several plant species in petri dish bioassays. They found that the exudates contained vanillic acid at a concentration that inhibited the growth of the test species in a bioassay. Otlewski et al. (1987) reported that watermelon seeds contained small peptides that function as protease inhibitors.

In a previous study we observed that watermelon seed exudates inhibited Proso millet radicle growth and Phytophthora capsici sporangia formation (Harrison et al., 2010). Exudates of some genotypes were highly inhibitory, whereas exudates of others did not inhibit growth. The objectives of this study were to determine if extractable components of watermelon testae contribute to the inhibitory properties of watermelon seed exudates and to assess the relative inhibitory potential of testa extracts from genetically diverse genotypes of watermelon and the related species C. colocynthis.

\section{Materials and Methods}

Testa tissue preparation. The genotypes included in this experiment were the watermelon cultivar, Charleston Gray, the U.S. Vegetable Laboratory experimental watermelon line, 406-1-x 7, a watermelon germplasm accessions, PI 167125, three citron melon, C. lanatus var. citroides germplasm accessions, PI 482246, PI 500354, and PI 532738 , and two accessions from the related species C. colocynthis, PI 432334 and PI 432337. Seeds used in this experiment were obtained from ripe fruit produced on greenhouse-grown plants that were selfpollinated. Seeds were thoroughly rinsed and air-dried after harvest and stored at $5{ }^{\circ} \mathrm{C}$. Seeds were bisected with scissors, and all tissues except the testa were removed with a dissecting needle. Testae were ground to pass through a 60 -mesh screen using a Wiley mill and lyophilized. Dried and ground testae were stored under nitrogen at $-25{ }^{\circ} \mathrm{C}$ until they were extracted.

Testa extraction. Ground testae were extracted first with dichloromethane to remove soluble nonpolar components and then with $70 \%$ methanol to extract the more polar soluble components. Extraction was accomplished by placing $3 \mathrm{~g}$ of the tissue in a roundbottomed flask with $45 \mathrm{~mL}$ solvent. The slurry was placed on a wrist action shaker at $50 \mathrm{rpm}$ in the dark at room temperature for $24 \mathrm{~h}$. Testae were extracted twice with both solvents and the two extractions with the same solvent were combined. Extracts were filtered through nylon 66 filters $(0.8 \mu \mathrm{m})$, dried on a rotary evaporator, and stored at $-25{ }^{\circ} \mathrm{C}$ under nitrogen until they were used in bioassay experiments.

Proso millet bioassay. The $70 \%$ methanol extracts were re-dissolved in $70 \%$ methanol 
to obtain an extract concentration equivalent to $250 \mathrm{mg}$ of testa extracted per $\mathrm{mL}$. Aliquots of the extract plus additional $70 \%$ methanol to equal $0.5 \mathrm{~mL}$ total volume were pipetted onto filter paper disks in $35-\mathrm{mm}$ plastic petri dishes. The solvent was allowed to evaporate at room temperature. Ten Proso millet seeds and $0.5 \mathrm{~mL}$ of distilled water were subsequently added to each dish, and the seeds were incubated in the dark at $24{ }^{\circ} \mathrm{C}$. After $72 \mathrm{~h}$, the petri dishes were placed in a freezer to stop growth. The dishes were removed from the freezer, millet radicle lengths were measured with an electronic caliper, and average radicle length was determined for each dish. For the dichloromethane extract, the extracts were re-dissolved in dichloromethane to obtain a concentration of $250 \mathrm{mg}$ testa extracted per $\mathrm{mL}$. The extracts plus additional dichloromethane to bring the total volume to $1 \mathrm{~mL}$ were pipetted onto filter paper in 50-mm glass petri dishes. The solvent was evaporated at room temperature and $1 \mathrm{~mL}$ of distilled water and 20 Proso millet seeds were added to each dish. The seeds were incubated, frozen, and radicle lengths measured as described previously.

A preliminary experiment examined the effect of the sequential dichloromethane and $70 \%$ methanol extracts. The extract concentrations were equivalent to $100 \mathrm{mg}$ testa extracted per $\mathrm{mL}$ water. The experiment was arranged in a completely random design with five replications and was repeated. Data were analyzed using the PROC GLM procedure of SAS Version 9.1 (SAS Institute, Cary, NC). No treatment-by-experiment interactions were observed; thus, the combined data from two repetitions of the experiments were subjected to analysis of variance, and genotype means within extraction solvents were separated by Tukey's honestly significant difference (HSD) test $(P=0.05)$.

A second experiment was conducted to assess the concentration response to the $70 \%$ methanol testa extracts. The methods of extraction are described previously. Test concentrations were equivalent to $0,31,63$, 125 , and $250 \mathrm{mg} \cdot \mathrm{mL}^{-1}$. The experiment was arranged in a completely randomized design with five replications. Radicle lengths were analyzed using the PROC GLM procedure of SAS Version 9.1. No treatment-by-experiment interaction was observed; thus, data from the two repetitions of the experiment were combined for analysis. Genotype means within extract concentrations were separated using Tukey's standardized range HSD $(P=0.05)$. Nonlinear regression analyses (proc nlin; SAS System; SAS Institute) using the parallel dose-response curves procedure described by Seefeldt et al. (1995) were used to estimate the $70 \%$ methanol extract concentration required to cause a $50 \%$ reduction in radicle length $\left(\mathrm{GR}_{50}\right)$ for each genotype.

Acidovorax avenae bioassay. The bacterial fruit blotch pathogen, Aac, isolate 531 was obtained under USDA, APHIS permit from Dr. Ron Walcott, University of Georgia, Athens, GA. Isolate 531 was originally isolated from infected watermelon fruit from Georgia and has been identified as a Group I isolate (Wechter et al., 2011). The bacterium was started from $-80{ }^{\circ} \mathrm{C}$ glycerol freezer stocks for each experiment. The isolate was streaked onto Difco ${ }^{\mathrm{TM}}$ nutrient agar (NA) medium (Becton, Dickinson and Company, Sparks, MD) and grown for $24 \mathrm{~h}$ at $27^{\circ} \mathrm{C}$. A single colony from the 24-h-old plates was again transferred to an NA plate and grown for an additional $24 \mathrm{~h}$. A $10-\mu \mathrm{L}$ loop of cells from this plate was inoculated into $100 \mathrm{~mL}$ of King's B broth and place on a gyratory shaker at $150 \mathrm{RPM}$ until midlog phase growth $(\approx 0.8$ $\left.\mathrm{OD}_{600}\right)$ as determined by Biophotometer (Eppendorf, Westbury, NY). Cells were pelleted by centrifugation at 10,000 RCF. Supernatant was discarded and cell pellet washed once with sterile $0.01 \mathrm{M}$ phosphate-buffered saline (sPBS), again pelleted by centrifugation, and then resuspended in sPBS to a concentration of $\approx 1 \times 10^{8}$ colony-forming units $(\mathrm{CFU}) / \mathrm{mL}$ as determined by optical density at a wavelength $600 \mathrm{~nm}$.

Bacterial assays were performed in 96well polystyrene microtiter plates. One milliliter aliquots of re-solubilized testa extracts were pipetted into polypropylene microcentrifuge tubes and placed, uncapped, into a $50{ }^{\circ} \mathrm{C}$ dry-block heater in a sterile hood until all trace of solvent was gone. In addition, $1 \mathrm{~mL}$ of solvent (either methanol or dichloromethane, depending on the test) was pipetted into a microcentrifuge tube and evaporated to dryness as in a similar fashion. One milliliter of sterile King's B broth was added to each microcentrifuge tube. Tubes were capped and vortexed until contents were fully suspended. Three hundred-microliter aliquots of each resuspended extract as well as the solvent controls were pipetted in triplicate into individual wells of the microtiter plate. Six additional empty wells also received $300 \mu \mathrm{L}$ of King's B to be used as with and without bacteria controls. All wells then received $25 \mu \mathrm{L}$ of the $1 \times 10^{8} \mathrm{CFU} / \mathrm{mL}$ Aac described previously with the exception of the "withoutbacteria" control wells, which received $25 \mu \mathrm{L}$ sPBS. Plates were covered and placed on a rotary shaker (50 RPM) in a $28^{\circ} \mathrm{C}$ incubator. After $24 \mathrm{~h}$ of growth, $10-\mu \mathrm{L}$ aliquots were removed from each well and added to $990 \mu \mathrm{L}$ of King's B broth in a microcentrifuge tube. The contents of these tubes were serially diluted by 10 -fold and $100 \mu \mathrm{L}$ of each dilution was spread-plated onto two petri plates of Pseudomonas agar F. Plates were incubated at $28^{\circ} \mathrm{C}$ for $36 \mathrm{~h}$ and colonies were tallied. Each test was performed twice. The dilution that allowed all treatments to be scored (i.e., the lowest dilution at which colonies were not too numerous to count) was used for counts. An average CFU was taken for the two plates at the chosen dilution and used in the statistical analysis. Data were analyzed using the PROC GLM procedure of SAS Version 9.1 (SAS Institute). Significant experiment-by-treatment interactions were found for both the dichloromethane and methanol extracts; thus, the data from each test were analyzed separately. Genotype means within extraction solvents were separated using Tukey's standardized range $\operatorname{HSD}(P=0.05)$.
Phythophthora capsici bioassay. An isolate of the plant pathogen Phytophthora capsici was obtained from Dr. A.P. Keinath, Clemson University. This isolate of $P$. capsici is highly aggressive on watermelon (Kousik et al., unpublished data). The isolate had been maintained on V8 juice agar in the laboratory (Keinath, 2007; Keinath and Kousik, 2011). Zoospore germination assays were conducted using methods described by Keinath and Kousik (2011) with slight modifications as follows. One hundred microliters of resolubilized $70 \%$ methanol testa extracts were pipetted into $2-\mathrm{mL}$ polypropylene microcentrifuge tubes and placed, uncapped, into a $50{ }^{\circ} \mathrm{C}$ dry-block heater in a sterile hood until all trace of solvent was gone. In addition, $100 \mu \mathrm{L}$ of $70 \%$ methanol was pipetted into a microcentrifuge tube and evaporated to dryness in a similar fashion. Once the tubes were completely dry of all traces of solvent, 100 $\mu \mathrm{L}$ of a zoospore suspension in sterile distilled water, prepared as described by Keinath and Kousik (2011) was pipetted into the 2$\mathrm{mL}$ microcentrifuge tubes. The tubes were capped and vortexed vigorously until contents were completely suspended. This action also enables the zoospores to encyst (Keinath, 2007; Keinath and Kousik, 2011). The tubes were placed in a rack and shook mildly for $1 \mathrm{~h}$ at $26{ }^{\circ} \mathrm{C}$. Then, the suspensions were plated on $1 \%$ water agar plates as described previously (Keinath, 2007; Keinath and Kousik, 2011) and placed in an incubator at $26^{\circ} \mathrm{C}$ for another $90 \mathrm{~min}$ after which germinated and ungerminated zoospores were counted. Each testa extract was tested on four plates, which served as replications, and two germination counts per replication were recorded. The experiment was repeated once. Data were arsine transformed and analyzed using the PROC GLM procedure of SAS Version 9.1 (SAS Institute). Significant treatment-by-experiment interactions were observed; thus, the data from each experiment were analyzed separately. Genotype means were separated using Tukey's standardized range HSD $(P=0.05)$.

\section{Results and Discussion}

Proso millet bioassay. The dichloromethane extracts contained fatty material that changes the absorptive properties of the filter paper in comparison with the control that was treated with dichloromethane only; however, they did not inhibit radicle growth at 100 $\mathrm{mg} \cdot \mathrm{mL}^{-1}$ (Table 1$)$. Given the high inhibition of the methanol extract of some genotypes, we concluded that the soluble nonpolar components of watermelon testae do not contribute greatly to the inhibition of Proso millet radicle growth observed with seed exudates (Harrison et al., 2010). The 70\% methanol extracts of four genotypes, one watermelon genotype ('Charleston Gray'), one citron melon genotype (PI 532738), and both of the C. colocynthis genotypes inhibited radicle growth at $100 \mathrm{mg} \cdot \mathrm{mL}^{-1}$ (Table 1). The concentration response experiment also indicated differences between Citrullus genotypes in inhibitory potential of $70 \%$ methanol extracts 
Table 1. Response of Proso millet radicle growth to dichloromethane and $70 \%$ methanol extracts ${ }^{\mathrm{z}}$ of testa of eight Citrullus genotypes.

\begin{tabular}{|c|c|c|c|}
\hline \multirow[b]{2}{*}{ Genotype } & \multirow[b]{2}{*}{$\begin{array}{c}\text { Citrullus species } \\
\text { and variety }\end{array}$} & \multicolumn{2}{|c|}{ Radicle length (mm) } \\
\hline & & $\begin{array}{c}\text { Dichloromethane } \\
\text { extract }^{\mathrm{y}}\end{array}$ & $\begin{array}{c}70 \% \text { methanol }^{\text {extract }}{ }^{\mathrm{y}} \\
\text { ex }\end{array}$ \\
\hline Charleston Gray & lanatus var. lanatus & 18.8 & $15.1 \mathrm{bc}$ \\
\hline $406-1-\times 7$ & lanatus var. lanatus & 19.2 & $17.5 \mathrm{ab}$ \\
\hline PI 167125 & lanatus var. lanatus & 21.1 & $20.0 \mathrm{ab}$ \\
\hline PI 482246 & lanatus var. citroides & 23.4 & $17.2 \mathrm{ab}$ \\
\hline PI 500354 & lanatus var. citroides & 22.9 & $22.4 \mathrm{a}$ \\
\hline PI 532738 & lanatus var. citroides & 19.0 & $9.56 \mathrm{~cd}$ \\
\hline PI 432334 & colocynthis & 19.4 & $15.1 \mathrm{bc}$ \\
\hline PI 432337 & colocynthis & 24.5 & $5.2 \mathrm{~d}$ \\
\hline Control & & 20.5 & $21.4 \mathrm{a}$ \\
\hline$P$ value ${ }^{\mathrm{x}}$ & & 0.0103 & $<0.0001$ \\
\hline
\end{tabular}

${ }^{\mathrm{z} E x t r a c t s}$ were tested at a concentration equivalent to $100 \mathrm{mg}$ testa tissue extracted per $\mathrm{mL}$.

${ }^{y}$ Means within $70 \%$ methanol extracts followed by the same letter are not different by Tukey's honestly significant difference $(P=0.05)$ test. Means within the dichloromethane extracts were not different by the test.

${ }^{\mathrm{x}}$ Significance level of the F test for genotype effect on Proso millet radicle growth.

Table 2. Concentration ${ }^{z}$ response of Proso millet radicle growth to $70 \%$ methanol extracts of testa from eight Citrullus genotypes.

\begin{tabular}{|c|c|c|c|c|c|c|}
\hline \multirow[b]{2}{*}{ Genotype } & \multirow{2}{*}{$\begin{array}{l}\text { Citrullus species } \\
\text { and variety }\end{array}$} & \multicolumn{4}{|c|}{ Radical length $^{\mathrm{y}}(\mathrm{mm})$} & \multirow{2}{*}{$\begin{array}{c}\mathrm{GR}_{50}{ }^{\mathrm{x}} \\
\left(\mathrm{mg} \cdot \mathrm{kg}^{-1}\right)\end{array}$} \\
\hline & & $31 \mathrm{mg} \cdot \mathrm{mL}^{-1}$ & $63 \mathrm{mg} \cdot \mathrm{mL}^{-1}$ & $125 \mathrm{mg} \cdot \mathrm{mL}^{-1}$ & $250 \mathrm{mg} \cdot \mathrm{mL}^{-1}$ & \\
\hline Charleston Gray & lanatus var. lanatus & $25.8 \mathrm{ab}$ & $24.6 \mathrm{ab}$ & $16.9 \mathrm{abc}$ & $7.9 \mathrm{~b}$ & $171 \pm 18$ \\
\hline $406-1-x 7$ & lanatus var. lanatus & $21.9 \mathrm{~b}$ & $21.6 \mathrm{bc}$ & $16.1 \mathrm{abc}$ & $10.0 \mathrm{~b}$ & $173 \pm 18$ \\
\hline PI 167125 & lanatus var. lanatus & $24.4 \mathrm{~b}$ & $24.8 \mathrm{ab}$ & $19.5 \mathrm{ab}$ & $9.0 \mathrm{~b}$ & $196 \pm 20$ \\
\hline PI 482246 & lanatus var. citroides & $25.8 \mathrm{ab}$ & $24.7 \mathrm{ab}$ & $17.0 \mathrm{abc}$ & $10.4 \mathrm{~b}$ & $191 \pm 20$ \\
\hline PI 500354 & lanatus var. citroides & $30.7 \mathrm{a}$ & $29.1 \mathrm{a}$ & $20.0 \mathrm{ab}$ & $9.6 \mathrm{~b}$ & $211 \pm 21$ \\
\hline PI 532738 & lanatus var. citroides & $26.4 \mathrm{ab}$ & $19.8 \mathrm{bc}$ & $10.0 \mathrm{~cd}$ & $1.5 \mathrm{c}$ & $102 \pm 11$ \\
\hline PI 432334 & colocynthis & $24.7 \mathrm{ab}$ & $24.0 \mathrm{ab}$ & $12.9 \mathrm{bcd}$ & $5.5 \mathrm{bc}$ & $134 \pm 14$ \\
\hline PI 432337 & colocynthis & $22.6 \mathrm{~b}$ & $16.6 \mathrm{c}$ & $7.0 \mathrm{~d}$ & $1.7 \mathrm{c}$ & $80 \pm 9$ \\
\hline Control & & $22.3 \mathrm{~b}$ & $22.3 \mathrm{abc}$ & $22.3 \mathrm{a}$ & $22.3 \mathrm{a}$ & - \\
\hline$P$ value $^{\mathrm{w}}$ & & 0.0041 & 0.0001 & $<0.0001$ & $<0.0001$ & \\
\hline
\end{tabular}

${ }^{\mathrm{z}}$ Concentrations are expressed as weight of testa extracted per $\mathrm{mL}$ water.

${ }^{\mathrm{y}}$ Means within concentrations followed by the same letter are not different by Tukey's honestly significant difference $(P=0.05)$.

${ }^{x}$ The concentration of extract that caused a $50 \%$ reduction in shoot length $\left(\mathrm{GR}_{50}\right)$ was estimated for each

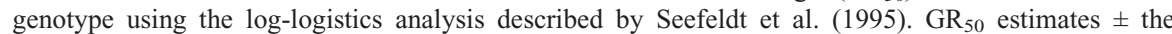
approximate SE of the estimate are presented.

wSignificance level of the F test for genotype effect on Proso millet radicle growth.

(Table 2). At $31 \mathrm{mg} \cdot \mathrm{mL}^{-1}$, no genotypes inhibited radicle growth in comparison with the control. At this concentration, means were different as a result of an apparent stimulation of radicle growth by the PI 500354 extract that resulted in radicle lengths greater than the control. At $63 \mathrm{mg} \cdot \mathrm{mL}^{-1}$, none of the extracts were different from the control; however, there were differences between genotypes as a result of the apparent stimulation of radicle growth by PI 500354 and slight inhibition by other genotypes. Neither stimulated nor inhibited radicle lengths were different from the control, but they were different from each other. At 125 $\mathrm{mg} \cdot \mathrm{mL}^{-1}$, extracts of three genotypes, the $C$. lanatus, var. citroides accession PI 532738 and both $C$. colocynthis accessions, inhibited radicle growth compared with the control. At 250 $\mathrm{mg} \cdot \mathrm{mL}^{-1}$, extracts of all genotypes inhibited radicle growth in comparison with the control. Two genotypes (PI 532738 and PI 432337) that were inhibitory in the preliminary experiment (Table 1) caused the greatest inhibition of radicle growth at this concentration. Seed exudates of these genotypes were also highly inhibitory in a Proso millet bioassay (Harrison et al., 2010). $\mathrm{GR}_{50}$ estimates indicated that the extracts of PI 432337 were over twice as inhibitory as the extracts of PI 500354.

Acidovorax avenae bioassay. The dichloromethane methane extracts of all but two genotypes, 406-1-x and PI 500354, were highly inhibitory to CFU formation by Aac (Table 3). The 406-1-x7 extract inhibited CFU counts compared with both controls in Expt. 1, counts with the PI 500354 extract were lower than the solvent control in Expt. 1, but counts with the two extracts were not different from the controls in Expt. 2. Aac CFU counts in dichloromethane extracts of the six highly inhibitory genotypes were lower than both controls and 406-1-x and PI 500354 extracts in both experiments. Overall, inhibition of Aac growth was greater for the dichloromethane extracts than for the $70 \%$ methanol extracts. Averaged over genotypes and experiments, CFU counts were $22 \%$ of control in dichloromethane extracts and $37 \%$ of control in $70 \%$ methanol extracts. The $70 \%$ methanol extracts of the watermelon genotypes, 'Charleston Gray', 406-1-x, and PI 167125, and the citron melon genotype, PI 532738, inhibited Aac growth in comparison with both controls and PI 482246, PI 500354, PI 432334, and PI 432337 extracts in both experiments. The PI 532738 extract was the only $70 \%$ methanol extract that completely inhibited Aac growth.

Phytophthora capsici bioassay. P. capsici zoospore germination was high (greater than $70 \%$ ) in the water and the solvent control. The 70\% methanol extracts of 'Charleston Gray', 406-1-x 7, PI 167125, PI 500354, and PI 532738 were highly inhibitory to $P$. capsici zoospore germination in both tests (Table 4) in which germination was lower than both of the controls. The testa extracts of the C. colocynthis accessions were not inhibitory to zoospore germination. It is interesting to note that the testa extract of PI 500354 was inhibitory to zoospores of $P$. capsici, although the fruit rind is highly susceptible to fruit rot (Kousik, unpublished data). This may indicate that the inhibitory substances extracted from testa are not involved in resistance to the fruit rot disease or that they or not present in inhibitory concentrations in the fruit rind of this genotype. The results of this experiment do not correspond closely to the inhibition of sporangial formation by seed exudates observed in a previous experiment (Harrison et al., 2010) where the C. colocynthis genotypes were highly inhibitory and $C$. lanatus genotypes were not. The reasons for this discrepancy are not known; however, it may be the result of differences in the $P$. capsici growth parameters that were measured in the two bioassays or a more thorough removal of inhibitors by extraction in comparison with the seed leachate. The dichloromethane extracts were not tested against $P$. capsici as a result of difficulties with the procedure, and the seed leachate may have contained inhibitors found in these extracts, but not in the $70 \%$ methanol extracts.

These experiments demonstrate that the inhibitory properties of watermelon seed exudates observed in previous studies (Harrison et al., 2010) are at least partially the result of extractable components in the testa. This nonliving, maternal tissue may serve as a storage site for inhibitory compounds that protect the embryo from predation or infection before germination and during the early stages of seedling growth. Extract concentrations of $100 \mathrm{mg}$ of testa extracted per $\mathrm{mL}$ medium caused strong inhibition of pathogenic microorganisms (Tables 3 and 4). This extract concentration is approximately equivalent of a 1:10 (w:w) dilution of the extractable material relevant to its concentration within the testae. Inhibitors extractable in $70 \%$ methanol probably leach out of the testa during seed imbibition and may reach microorganism growth-inhibiting concentrations that protect the germinating seedling. Testae components could not cause the allelopathic potential of watermelon seedlings and roots that has been demonstrated in greenhouse and field experiments (Hao et al., 2007; Kushima et al., 1998). However, it is possible that the compounds found in testa are synthesized in living tissues and released into the soil to cause plant inhibition. High levels of pest resistance are reported in some $C$. lanatus var. citroides and 
Table 3. Growth of Acidovorax avenae subsp. citrulli after incubation in King's B broth amended with dichloromethane and $70 \%$ methanol extracts ${ }^{\mathrm{z}}$ of testae of eight Citrullus genotypes.

\begin{tabular}{|c|c|c|c|c|c|}
\hline \multirow[b]{3}{*}{ Accession } & \multirow[b]{3}{*}{ Citrullus species } & \multicolumn{2}{|c|}{ Dichloromethane extract ${ }^{y}$} & \multicolumn{2}{|c|}{$70 \%$ methanol extract ${ }^{y}$} \\
\hline & & Expt. 1 & Expt. 2 & Expt. 1 & Expt. 2 \\
\hline & & ------------ & (CF & 0) -----. & 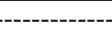 \\
\hline$\overline{406-1-x} 7$ & lanatus var. lanatus & $205.8 \mathrm{c}$ & $417.5 \mathrm{a}$ & $70.5 \mathrm{de}$ & $26.5 \mathrm{~d}$ \\
\hline PI 167125 & lanatus var. lanatus & $1.0 \mathrm{~d}$ & $0.3 \mathrm{~b}$ & $89.8 \mathrm{de}$ & $3.5 \mathrm{~d}$ \\
\hline PI 482246 & lanatus var. citroides & $31.8 \mathrm{~d}$ & $49.2 \mathrm{~b}$ & $350.7 \mathrm{~b}$ & $357.5 \mathrm{~b}$ \\
\hline PI 500354 & lanatus var. citroides & $282.0 \mathrm{bc}$ & $450.5 \mathrm{a}$ & $290.5 \mathrm{bc}$ & $185.2 \mathrm{c}$ \\
\hline PI 532738 & lanatus var. citroides & $0.8 \mathrm{~d}$ & $0.7 \mathrm{~b}$ & $0.0 \mathrm{e}$ & $0.0 \mathrm{~d}$ \\
\hline PI 432334 & colocynthis & $35.2 \mathrm{~d}$ & $35.8 \mathrm{~b}$ & $296.7 \mathrm{bc}$ & $393.8 \mathrm{~b}$ \\
\hline PI 432337 & colocynthis & $44.5 \mathrm{~d}$ & $7.3 \mathrm{~b}$ & $396.7 \mathrm{ab}$ & $444.5 \mathrm{ab}$ \\
\hline Charleston Grey & lanatus var. lanatus & $0.0 \mathrm{~d}$ & $0.0 \mathrm{~b}$ & $198.3 \mathrm{dc}$ & $86.2 \mathrm{~cd}$ \\
\hline Control $^{x}$ & & 432. a & $440.0 \mathrm{a}$ & $510.7 \mathrm{a}$ & $562.2 \mathrm{a}$ \\
\hline Solvent control ${ }^{\mathrm{w}}$ & & $357.5 \mathrm{ab}$ & $559.7 \mathrm{a}$ & $530.0 \mathrm{a}$ & $370.8 \mathrm{~b}$ \\
\hline Negative controlv & & $0.0 \mathrm{~d}$ & $0.0 \mathrm{~b}$ & $0.0 \mathrm{e}$ & $0.0 \mathrm{~d}$ \\
\hline$P$ value ${ }^{\mathrm{u}}$ & & $<0.0001$ & $<0.0001$ & $<0.0001$ & $<0.0001$ \\
\hline
\end{tabular}

${ }^{\mathrm{z}}$ Extracts were tested at a concentration of $100 \mathrm{mg}$ testa tissue extracted per $\mathrm{mL}$.

${ }^{y}$ Means within columns followed by the same letter are not significantly different based on Tukey's honestly significant difference $(P=0.05)$.

${ }^{x}$ King's B broth plus bacterium.

wKing's B broth added to evaporated dichloromethane or $70 \%$ methanol tube then used in microtitre assay plus bacterium.

'King's B with no added bacterium.

"Significance level of the $\mathrm{F}$ test for genotype effect on $A$. aveanae growth.

$\mathrm{CFU}=$ colony-forming unit.

Table 4. Effect of $70 \%$ methanol extracts ${ }^{\mathrm{z}}$ of testae of eight Citrullus genotypes on Phytophthora capsici zoospore germination.

\begin{tabular}{|c|c|c|c|}
\hline \multirow[b]{2}{*}{ Genotype } & \multirow[b]{2}{*}{ Citrullus species } & \multicolumn{2}{|c|}{${\text { Germination }(\%)^{y}}^{y}$} \\
\hline & & Expt. 1 & Expt. 2 \\
\hline PI 482246 & lanatus var. citroides & $88.9 \mathrm{a}$ & $78.8 \mathrm{~b}$ \\
\hline PI 432334 & colocynthis & $88.9 \mathrm{a}$ & $74.0 \mathrm{~b}$ \\
\hline PI 432337 & colocynthis & $76.1 \mathrm{a}$ & $77.0 \mathrm{~b}$ \\
\hline PI 500354 & lanatus var. citroides & $12.2 \mathrm{~b}$ & $16.6 \mathrm{~d}$ \\
\hline $406-1-X 7$ & lanatus var. lanatus & $5.9 \mathrm{bc}$ & $31.8 \mathrm{c}$ \\
\hline PI 167125 & lanatus var. lanatus & $2.3 \mathrm{bc}$ & $4.6 \mathrm{e}$ \\
\hline PI 532738 & lanatus var. citroides & $0.5 \mathrm{c}$ & $8.1 \mathrm{e}$ \\
\hline Charleston Gray & lanatus var. lanatus & $0.1 \mathrm{c}$ & $28.0 \mathrm{c}$ \\
\hline Solvent control & & $72.8 \mathrm{a}$ & $82.4 \mathrm{ab}$ \\
\hline Water control & & $70.5 \mathrm{a}$ & $88.6 \mathrm{a}$ \\
\hline$P$ value ${ }^{\mathrm{x}}$ & & $<0.0001$ & $<0.0001$ \\
\hline
\end{tabular}

${ }^{2}$ Testa extracts were tested at a concentration equivalent to $100 \mathrm{mg}$ testa extracted per $\mathrm{mL}$ distilled water. ${ }^{y}$ Means followed by the same letter in column are not significantly different based on Tukey's honestly significant difference $(P=0.05)$.

${ }^{\mathrm{x}}$ Significance level of the $\mathrm{F}$ test for genotype effect on zoospore germination.

C. colocynthis genotypes (Boyhan et al., 1994; Levi et al., 2001; Simmons and Levi, 2002; Thies and Levy, 2007). Further research is warranted to identify biologically active compounds in testae and other tissues of watermelon and related species and investigates their role in pest resistance and allelopathy.

\section{Literature Cited}

Boyhan, G.E., J.D. Norton, B.R. Abrahams, and N.H. Wen. 1994. A new source of resistance to anthracnose (Race 2) in watermelon. HortScience 29:111-112.

Hao, W., L. Ren, W. Rand, and Q. Shen. 2010. Allelopathic effects of root exudates from watermelon and rice plants on Fusarium oxysporum f.sp. niveum. Plant Soil 336:485-497.
Hao, Z.P., Q. Wang, P. Christie, and X.L. Li. 2007. Allelopathic potential of watermelon tissues and root exudates. Sci. Hort. 23:315-320.

Harrison, H.F., Jr., C.S. Kousik, and A. Levi. 2010. A survey of watermelon germplasm for inhibitory seed exudates. HortScience 43:138-142.

Higashinakasu, K., K. Yamada, H. Shigemori, and K. Hasegawa. 2004. Effects of seed exudates of several plant species during germination stage. Weed Biol. Manage. 4:171-175.

Keinath, A.P. 2007. Sensitivity of populations of Phytophthora capsici from South Carolina to mefenoxam, dimethomorph, zoxamide, and cymoxanil. Plant Dis. 91:743-748.

Keinath, A.P. and C.S. Kousik. 2011. Sensitivity of isolates of Phytophthora capsici from the eastern United States to fluopicolide. Plant Dis. 'First Look' paper. DOI: 10.1094/PDIS-03-11-0242, Posted 21 June 2011.
Kushima, M., H. Kakuta, S. Kosemura, S. Yamamura, K. Yamada, K. Yokotani-Tomita, and K. Hosegawa. 1998. An allelopathic substance isolated from germinating watermelon seeds. Plant Growth Regulat. 25:1-4.

Levi, A., C.E. Thomas, A.P. Keinath, and T. Wehner. 2001. Genetic diversity among watermelon (Citrullus lanatus and Citrullus colocynthis) accessions. Genet. Resources Crop Evol. 48: 559-566.

Lockerman, R.H. and A.R. Putnam. 1979. Evaluation of allelopathic cucumbers (Cucumis sativus) as an aid to weed control. Weed Sci. 27: 54-57.

Lockerman, R.H. and A.R. Putnam. 1981. Mechanisms for differential interference among cucumber (Cucumis sativus L.) accessions. Bot. Gaz. 142:427-430.

Nelson, E.B. 1990. Exudate molecules initiating fungal response to seeds and roots. Plant Soil 129:61-73.

Nelson, E.B. 2004. Microbial dynamics and interactions in the spermosphere. Annu. Rev. Phytopathol. 42:271-309.

Ohno, S., K. Tomita-Yokotani, S. Kosemura, M Node, T. Suzuki, and M. Amano. 2001. A species selective allelopathic substance from germinating sunflower (Helianthus annииs L.) seeds. Phytochemistry 56:577-581.

Otlewski, J., H. Whatley, A. Polanoski, and T. Wilusz. 1987. Amino acid sequences of trypsin inhibitors from watermelon (Citrullus vulgaris) and red bryony (Bryonia dioica) seeds. Biol. Chem. 368:1505-1507.

Putnam, A.R. and W.B. Duke. 1974. Biological suppression of weeds: Evidence for allelopathy in accession of cucumber. Science 185:370-372.

Rose, T.L., A. da Silva Conceicas, J. Xavier-Filho, L.A. Okorokov, K.V.S. Fernandes, F. Marty, D. Marty-Mazars, A.O. Carvalho, and V.M. Gomes. 2006. Defense proteins from Vigna unguiculata seed exudates: Characterization and inhibitory activity against Fusarium oxysporum. Plant Soil 286:181-191.

Seefeldt, S.S., J.E. Jensen, and E.P. Fuerst. 1995. Log-logistic analysis of dose response relationships. Weed Technol. 9:218-227.

Simmons, A.M. and A. Levi. 2002. Sources of whitefly (Homoptera:Aleyrodidae) resistance in Citrullus for the improvement of cultivated watermelon. HortScience 37:581-584.

Thies, J.A. and A. Levy. 2007. Characterization of watermelon (Citrullus lanatus var. citroides) for resistance to root knot watermelon. HortScience 42:1530-1533.

Wechter, W.P., A. Levi, K.-S. Ling, K.C. Kousik, and C.C. Block. 2011. Identification of resistance to Acidovorax avenae subsp. citrulli among melon (Cucumis spp.) Plant Introductions. HortScience 46:207-212.

Yamada, T., T. Anai, and K. Hasegawa. 1995. Lepidimoide, an allelopathic substance in the exudates from germinated seeds. Phytochemsitry 39:1031-1032.

Yu, J.Q. 2001. Autotoxic potential of cucurbit crops; phenomenon, chemicals, mechanisms and means to overcome. J. Crop Prod. 4:335-348.

Yu, J.Q. and Y. Matsui. 1994. Phytotoxic substances in the root exudates of Cucumis sativus L. J. Chem. Ecol. 20:21-31.

Yu, J.Q., S.Y. Shou, Y.R. Qian, and W.H. Hu. 2000. Autotoxic potential in cucurbit crops. Plant Soil 223:147-151. 